\title{
Control of Pseudoplusia includens (Walker, 1857) in the soybean culture with different insecticides
}

\author{
Controle de Pseudoplusia includens (Walker, 1857) na cultura de soja \\ com diferentes inseticidas
}

\begin{abstract}
Airton Rodrigues Pinto Junior ${ }^{1 *}$, Luiz Alberto Kozlowski ${ }^{1}$ and André Luís Lopes da Silva ${ }^{2}$
${ }^{1}$ Pontifícia Universidade Católica do Paraná, Centro de Ciências Agrárias e Ambientais, Agronomia Zootecnia e Medicina Veterinária. Br 376, km 14, Costeira, 83010-500 - São José dos Pinhais, PR -Brasil. ${ }^{2}$ Departamento de Engenharia de Bioprocessos e Biotecnologia; Universidade Federal do Paraná; 81531-970; Curitiba - PR - Brasil.
\end{abstract}

\begin{abstract}
The aim of this research was to test the efficacy of different insecticides, and dosage against Pseudoplusia includens in the soybean culture. The treatments were: (1) alphacypermethrin + teflubenzuron, (2) teflubenzuron, (3) diflubenzuron and (4) profenophos + lufenuron, in different doses. All the insecticides tested in this research presented high efficacy on the control of Pseudoplusia includens in the soybean culture. These insecticides and dosages were: (1) mixture of alphacypermethrin and teflubenzuron at dosages from 9.0 to $11.25 \mathrm{~g}$ a.i.ha ${ }^{-1}$, (2) teflubenzuron at dosage from 6 to $12 \mathrm{~g}$ a.i.ha $\mathrm{h}^{-1}$, (3) diflubenzuron at dosage from 10 to $20 \mathrm{~g}$ a.i.ha $\mathrm{a}^{-1}$ and (4) the mixture profenophos and lufenuron at dosage 75.0 and $7.5 \mathrm{~g}$ a.i.ha ${ }^{-1}$, respectively. All these insecticides after 15 days of application promote $100 \%$ dead caterpillars. None these insecticides decrease soybean yield.
\end{abstract}

Key-words: Glycine max., soybean looper, pesticides, lepidoptera, pests

\section{INTRODUCTION}

The soybean is one of the main products of export of Brazil. In 2002, the country exported 15.6 million tons of soybean grains, 12.5 million tons soybean bran and 1.7 million tons crude oil. The main buyers of the Brazilian grain are Holland (1.140.425 million tons), China (585.553 million tons), Germany (557.163 million tons) and Spain (371.146 million tons). The secret of the Brazilian competitiveness is in the high productivity of the culture. Besides, the planted area grew $18 \%$ in the decade of 90 and the average yield of the culture grew about $37.6 \%$, passing of $1740 \mathrm{~kg} \cdot \mathrm{ha}^{-1}$ for 2395 hg.ha ${ }^{-1}$. The state that more produces soybean in Brazil is Mato Grosso. Paraná is the second largest producing of the grain, planting an area of 3.5 million hectares with an average productivity of $3000 \mathrm{~kg} \cdot \mathrm{ha}^{-1}$ and production of 10.6 million tons. The third largest Brazilian producer is the Rio Grande do Sul state (EMBRAPA SOJA, 2003).

Considering to the immense production scale that the soybean culture reached (great areas planted in monoculture) it is inevitable the occurrence of phytosanitary problems. Among the pests that can attack the soybean plant are the leaf caterpillars. The main species is the velvetbean caterpillar (Anticarsia gemmatalis Hueb., 1818) main pest of the culture in the South of Brazil. Moreover, the occurrence of the others caterpillars is very common, such as: Long-tailed skipper (Urbanus proteus L., 1758), soybean leaf roller (Hedylepta indicata Fabr., 1794), soybean looper (Pseudoplusia includens Walker, 1857), cabbage looper (Rachiplusia nu Guen., 1852) (Gallo et al., 1988).

A. gemmatalis can be considered the main pest of the soybean culture, causing damages larger than caused by the soybean looper ( $P$. includens). However, the fact of these two species occurs in the same time does with that these caterpillars are considered the main pests that attack the soybean culture. The areas of larger occurrence of $P$. includens are the states of Paraná and São Paulo and the higher incidence occurs among December to February.

Author for correspondence: pinto.junior.airton@gmail.com

J. Biotec. Biodivers. v. 2, N.4: pp. 16-20, Nov. 2011 
The caterpillar $P$. includens presents green coloration, with white stripes on the back and it can present dark points on the body. These caterpillar feeds of leaves, but not of the nervures, checking a lacy aspect to the attacked leaves.

The efficacy of some insecticides for pests control on the soybean culture had been reported. Several lepidopterans species including $P$. includens has been efficiently controlled with diflubenzuron (Welland et al., 1997) and a reduction of populations of older nymphs was observed after the lufenuron application, but the degree and the duration of the suppression was dependent of to dosage used (Sechser et al., 2001).

Due to the lack of information to the chemical control of $P$. includens in the soybean culture, the aim of this research was to evaluate the insecticides efficacy: (1) alphacypermethrin + teflubenzuron, diflubenzuron and (4) profenophos + lufenuron, in different doses.

\section{MATERIAL AND METHODS}

The field assay was installed at Gralha Azul Experimental Farm of Pontifical Catholic University of Paraná, (metropolitan area of Curitiba), Paraná State. The soybean cultivar BRS 133 was used and it has sowed on November 05, 2003. The control of weeds was accomplished with the herbicide application. For the dicotyledon control was used Chlorimuron-ethyl $10 \mathrm{~g}$ a.i.ha ${ }^{-1}+$ lactofen $120 \mathrm{~g}$ a.i.ha ${ }^{-1}$ and for the monocotyledons (Clethodim $108 \mathrm{~g}^{2}$ a.i.ha ${ }^{-1}$ ). The spacing of $40 \mathrm{~cm}$ distance was used among lines with 12 plants for lineal meter. The treatments were the insecticides: (1) alphacypermethrin + teflubenzuron, (2) teflubenzuron, (3) diflubenzuron and (4) profenophos + lufenuron, according to the specifications of the Tables 1 and 2.

Table 1. Description of the products used for the control of the caterpillar Pseudoplusia includens on the soybean culture, by leaf spraying in the Fazenda Rio Grande County (PR), 2004. Legend: SC = Suspension concentrate, EC = Emulsifiable concentrate, $\mathrm{WP}=$ Wettable powder.

\begin{tabular}{|c|c|c|c|c|c|}
\hline $\begin{array}{c}\text { Commercial } \\
\text { name }\end{array}$ & Concentration $^{1}$ & Active ingredient & Formulation & $\begin{array}{c}\text { Toxicologica } \\
1 \text { class }\end{array}$ & $\begin{array}{c}\text { Chemical } \\
\text { group }\end{array}$ \\
\hline $\begin{array}{l}\text { Nomax BAS } \\
\text { 325WAI }\end{array}$ & $75+75$ g. $\mathrm{L}^{-1}$ & $\begin{array}{l}\text { alphacypermethrin } \\
+ \text { teflubenzuron }\end{array}$ & $\mathrm{SC}$ & --- & $\begin{array}{l}\text { pyrethroid } \\
\text { benzoylurea }\end{array}$ \\
\hline Curyon & $500+50$ g. $\mathrm{L}^{-1}$ & $\begin{array}{l}\text { profenophos } \\
\text { lufenuron }\end{array}$ & $\mathrm{EC}$ & II & $\begin{array}{l}\text { benzoylurea }+ \\
\text { organophosphate }\end{array}$ \\
\hline $\begin{array}{l}\text { Dimilin } \\
\text { Nomolt }\end{array}$ & $\begin{array}{l}250 \text { g. } \mathrm{Kg}^{-1} \\
150 \text { g.L }\end{array}$ & $\begin{array}{l}\text { diflubenzuron } \\
\text { teflubenzuron }\end{array}$ & $\begin{array}{l}\text { WP } \\
\text { SC }\end{array}$ & $\begin{array}{l}\text { IV } \\
\text { IV }\end{array}$ & $\begin{array}{l}\text { benzoylurea } \\
\text { benzoylurea }\end{array}$ \\
\hline
\end{tabular}

Table 2. Description of the treatments tested for the control of the caterpillar Pseudoplusia includens on the soybean culture, by leaf spraying in the Fazenda Rio Grande County (PR), 2004.

\begin{tabular}{|c|c|c|c|}
\hline \multirow[b]{2}{*}{ Treatment } & \multirow[b]{2}{*}{ Commercial name } & \multicolumn{2}{|c|}{ Dose } \\
\hline & & $\begin{array}{c}\text { L or Kg.ha }{ }^{-1} \\
\text { (commercial product) }\end{array}$ & $\begin{array}{c}\text { g a.i.ha }{ }^{-1} \quad \text { (active }^{\text {ingredient) }}\end{array}$ \\
\hline 1 & Control & -- & --- \\
\hline 2 & Nomax BAS 325WAI & 0.12 & $9.0+9.0$ \\
\hline 3 & Nomax BAS 325WAI & 0.15 & $11.25+11.25$ \\
\hline 4 & Nomolt & 0.08 & 12.0 \\
\hline 5 & Dimilin & 0.08 & 20.0 \\
\hline 6 & Curyon & 0.15 & $75.0+7.5$ \\
\hline 7 & Nomax BAS 325WAI & 0.075 & $5.625+5.625$ \\
\hline 8 & Nomolt & 0.04 & 6.0 \\
\hline 9 & Dimilin & 0.04 & 10.0 \\
\hline
\end{tabular}


An insecticide application was accomplished $(02 / 23 / 2004)$ when the infestation level of caterpillars reached a number of 10 individuals $(<$ $1.5 \mathrm{~cm})$ and 11 individuals $(>1.5 \mathrm{~cm})$ obtained by cloth beat method, being 21 caterpillars/cloth beta/parcel. The insecticide application was accomplished with precision equipment, pressurized with $\mathrm{CO}_{2}$, equipped with bar of $4.0 \mathrm{~m}$, contends 4 nozzles, conical emptiness, spaced to each other of $0.50 \mathrm{~m}$, being used a work pressure of $2.8 \mathrm{kgf} . \mathrm{cm}^{2}$ and a spray volume of $160 \mathrm{~L} \cdot \mathrm{ha}^{-1}$.

The efficacy evaluation of the different treatments consisted of two samples per portion, using the cloth beat, for obtaining of the total number of alive caterpillars $(<1.5$ and $>1.5 \mathrm{~cm})$, in all the experimental parcels, and the efficacy index was determined with base in the total number of alive caterpillars in the different treatments in relation to the total number of the alive caterpillars in the treatment control, using a percentile scale from 0 (all alive) to $100 \%$ (all died). The evaluations of the chemical control efficacy were accomplished at the $2,7,10,15,22$ and 30 days after the insecticide application.
The evaluation of the grain yield was accomplished in area of $4.0 \mathrm{~m}^{2}$ of the experimental parcel, and the plants were harvested, threshed and the grains were weighted and humidity was corrected at $13 \%$, being later on transformed to kg.ha ${ }^{-1}$.

The experimental design used was random blocks with 4 replicates. The experimental parcels had the dimensions of $10 \mathrm{~m}$ length and $4.0 \mathrm{~m}$ width, with total area of $40 \mathrm{~m}^{2}$ and useful area of $24 \mathrm{~m}^{2}(8.0 \mathrm{~m}$ $\mathrm{x} 3.0 \mathrm{~m}$ ). The obtained data were submitted to the Bartlett's test (test the homogeneity of variances), and after to the analysis of variance. Means were compared by the Tukey's test at $5 \%$ of probability. All data were analyzed with aid of Michigan State Statistical Program v. 2.10 (MSTAT-C, 1993).

\section{RESULTS AND DISCUSSION}

After two days of the insecticide application, just the mixture profenophos + lufenuron in the dosage of 0.15 L.ha $^{-1}$ was efficient $(84 \%$ dead caterpillars), being statistically significant from the other treatments (Table 3).

Table 3. Efficacy of different insecticides, in different doses, on the control of Pseudoplusia includens (Lepidoptera: Noctuidae) in the soybean culture in the Gralha Azul Experimental Farm, Fazenda Rio Grande County, PR. 2004.

\begin{tabular}{ccccccccc}
\hline $\mathbf{T}^{\mathbf{1}}$ & Dose & \multicolumn{7}{c}{ \% dead caterpillars } \\
\hline & (L or Kg.ha $^{-\mathbf{1}}$ ) & $\mathbf{2 ~ d a t ~}^{\mathbf{2}}$ & $\mathbf{4 ~ d a t}$ & $\mathbf{7 ~ d a t}$ & $\mathbf{1 0}$ dat & $\mathbf{1 5}$ dat & $\mathbf{2 2}$ dat & 30 dat \\
\hline 1 & - & $0 \mathrm{f}^{3}$ & $0 \mathrm{e}$ & $0 \mathrm{~d}$ & $0 \mathrm{c}$ & 0 & 0 & 0 \\
2 & 0.12 & $75 \mathrm{~b}$ & $83 \mathrm{~b}$ & $95 \mathrm{ab}$ & $100 \mathrm{a}$ & 100 & 100 & 100 \\
3 & 0.15 & $76 \mathrm{~b}$ & $87 \mathrm{ab}$ & $96 \mathrm{a}$ & $100 \mathrm{a}$ & 100 & 100 & 100 \\
4 & 0.08 & $48 \mathrm{~d}$ & $71 \mathrm{~d}$ & $95 \mathrm{ab}$ & $98 \mathrm{~b}$ & 100 & 100 & 100 \\
5 & 0.08 & $48 \mathrm{~d}$ & $70 \mathrm{~d}$ & $92 \mathrm{~b}$ & $98 \mathrm{~b}$ & 100 & 100 & 100 \\
6 & 0.15 & $84 \mathrm{a}$ & $89 \mathrm{a}$ & $96 \mathrm{a}$ & $100 \mathrm{a}$ & 100 & 100 & 100 \\
7 & 0.075 & $66 \mathrm{c}$ & $77 \mathrm{c}$ & $95 \mathrm{ab}$ & $100 \mathrm{a}$ & 100 & 100 & 100 \\
8 & 0.04 & $44 \mathrm{e}$ & $69 \mathrm{~d}$ & $94 \mathrm{ab}$ & $98 \mathrm{~b}$ & 100 & 100 & 100 \\
9 & 0.04 & $42 \mathrm{e}$ & $68 \mathrm{~d}$ & $85 \mathrm{c}$ & $100 \mathrm{a}$ & 100 & 100 & 100 \\
\hline $\mathrm{CV}(\%)$ & 3.2 & 2.4 & 1.6 & 1.0 & - & - & - \\
\hline
\end{tabular}

${ }^{1}$ Treatments tested (Details in Table 1 and 2$) ;{ }^{2}$ dat. Days after treatments (i.e. Insecticide application); ${ }^{3}$ Means followed by the same letter do not differ significantly at $\mathrm{P}<0.05$ (Tukey's test).

After four days of the insecticide application, the mixture alphacypermethrin + teflubenzuron in the dosage $0.15 \mathrm{~L} . h a^{-1}$ (87\% dead caterpillars) and the mixture of the profenophos + lufenuron $(89 \%$ dead caterpillars) were efficient differing statistically of the other treatments (Table 3). Seven days after the insecticide application, all the insecticides tested were efficient for control of the $P$. includens, varying from 85 to $96 \%$ dead caterpillars. Similar results were observed to the 10 days of the insecticide application, varying from 98 to $100 \%$ of dead caterpillars. After 15 days of the insecticide application, it was observed that all the insecticides promoted the death of $100 \%$ caterpillars (Table 3). Similar results were observed in the control of several caterpillar species (lepidopterans) in the cotton culture using diflubenzuron, including the control of $P$. includens (Welland et al., 1997). 
The growth regulators, diflubenzuron, lufenuron, methoxyfenozoide and teflubenzuron had its efficacy checked against Anticarsia gemmatalis (Silva et al., 2003). The insecticides diflubenzuron, lufenuron and teflubenzuron controlled big and small larvae efficiently until 4 days after its application. It was observed in the control (treatment without the insecticide application) great loss of leaves of the plants and consequent decrease of the yield compared with the parcels treated with the growth regulators, agreeing with the results obtained in this research.

There were not significant statistical differences among the treatments with insecticide application on the productivity (Figure 1), except for the control that differed of the other treatments with insecticide application; the average productivity was $997.7 \mathrm{Kg} . \mathrm{ha}^{-1}$.

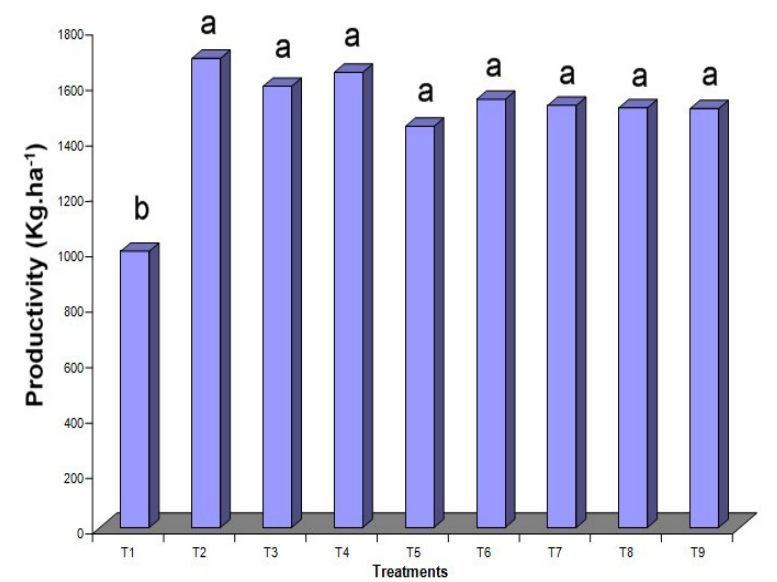

Figure 1 - Average productivity of different parcels treated with different insecticides for the control of Pseudoplusia includens (Lepidoptera: Noctuidae) in the soybean culture in the Gralha Azul Experimental Farm, Fazenda Rio Grande County, PR. 2004. Legend: T1: control; T2: NOMAX - BAS 325 I (alphacypermethrin + teflubenzuron) (0.12 L.ha $\left.{ }^{-1}\right)$; T3: NOMAX - BAS 325 I (alphacypermethrin + teflubenzuron) $\left(0.15 \mathrm{~L}^{-h^{-1}}\right)$; T4: teflubenzuron (0.08 L.ha $\left.{ }^{-1}\right)$; T5: diflubenzuron $\left(0.08 \mathrm{Kg}^{-h a}{ }^{-1}\right)$; T6: profenophos + lufenuron $\left(0.15 \mathrm{~g} . \mathrm{L}^{-}\right.$ $\left.{ }^{1}\right)$; T7: NOMAX - BAS 325 I (alphacypermethrin + teflubenzuron) (0.075 L.ha $\left.{ }^{-1}\right)$; T8: teflubenzuron $(0.04$ L.ha $\left.{ }^{-1}\right)$; T9: diflubenzuron (0.04 Kg.ha $\left.{ }^{-1}\right)$.

Significant differences were not observed among the blocks. The treatment that presented the largest average productivity was the mixture alphacypermethrin + teflubenzuron at dosage of $0.12 \mathrm{~L} \mathrm{ha}^{-1}$ and the smallest average was found with diflubenzuron at dosage of $0.08 \mathrm{~kg} \cdot \mathrm{ha}^{-1}$, even so without statistical differences (Figure 1).

\section{CONCLUSIONS}

All the insecticides tested in this research presented high efficacy on the control of Pseudoplusia includens in the soybean culture. These insecticides were: (1) mixture of alphacypermethrin and teflubenzuron at dosages from 9.0 to $11.25 \mathrm{~g}$ a.i.ha ${ }^{-1}$, (2) teflubenzuron at dosage from 6 to $12 \mathrm{~g}$ a.i.ha ${ }^{-1}$, (3) diflubenzuron at dosage from 10 to $20 \mathrm{~g}$ a.i.ha ${ }^{-1}$ and (4) the mixture profenophos and lufenuron at dosage 75.0 and 7.5 g a.i.ha ${ }^{-1}$, respectively. All these insecticides after 15 days of application promote $100 \%$ dead caterpillars. None these insecticides decrease soybean yield.

\section{RESUMO}

O objetivo desse trabalho foi testar a eficácia de diferentes inseticidas e doses para o controle da Pseudoplusia includens em soja. Os tratamentos consistiram de: (1) alfacipermetrina e teflubenzuron, (2) teflubenzuron, (3) diflubenzuron e (4) profenofós e lufenuron, em diferentes dosagens. Todos os inseticidas testados nessa pesquisa apresentaram alta eficiência no controle de Pseudoplusia includens em soja. Esses inseticidas e dosagens foram: (1) mistura de alfacipermetrina e teflubenzuron nas dosagens de 9,0 a 11,25 g i.a.ha ${ }^{-1}$, (2) teflubenzuron na dosagem de 6 a 12 g i.a.ha ${ }^{-1}$, (3) diflubenzuron nas dosagens de 10 a $20 \mathrm{~g}$ i.a.ha ${ }^{-1} \mathrm{e}$ (4) profenofós e lufenuron na dosagem de 75,0 e 7,5 g i.a.ha ${ }^{-1}$, respectivamente. Todos os inseticidas aos 15 dias da aplicação promoveram $100 \%$ de morte nas lagartas. Nenhum destes inseticidas diminui a produtividade da cultura.

Palavras-chave: Glycine max., lagarta falsa-medideira, pesticidas, Lepidóptera, pragas

\section{REFERENCES}

EMBRAPA SOJA - Empresa Brasileira de Pesquisa Agropecuária (2003), Retirado do site:http://www.cnpso.embrapa.br no seguinte endereço:/http://www.cnpt.embrapa.br/not0008.ht $\mathrm{m}$ em 02 de junho de 2004.

Gallo, D.; Nakano, O.; Neto, S.S.; Carvalho, R. P. L.; Batista, G. C.; Berti Filho, E.; Parra, J.R.P.; Zucchi, R.A.; Alves, S.B.; Vendramim, J.D. (1988), Manual de entomologia agrícola. $2^{\mathrm{a}}$ Ed. São Paulo, Ceres, 649 p.

MSTAT-C. (1993). User's guide to MSTAT-C. Michigan State Univ., E. Lansing. 
Sechser, B.; Ayoub, S.; Monuir, N.; Vogt, H. (ed.); E. Vinuela (ed.); J. Jacas. (2001), Selectivity of lufenuron $(\operatorname{Match}(\mathrm{R}))$, profenofos and mixtures of both versus cotton predators. Working Group 'Pesticides and Beneficial Organisms'. Proceedings of the meeting at Castello de la Plana, Spain, 18-20 October, 2000. BulletinOILB-SROP, 24: 121-136.

Silva, M. T. B.; Costa, E. C.; Boss, A.; Silva, M. T. B. (2003), Control of Anticarsia gemmatalis Hubner (Lepidoptera: Noctuidae) larvae with insect growth regulators. Ciência Rural, 33, 601605.
Welland, R. T.; McDonald, P. T.; Kish, M. K. (1997), Efficacy of Dimilin R (diflubenzuron) and transgenic $\mathrm{Bt}$ cotton on several lepidopteran species. Proccedings Beltwide Cotton Conferences, New Orleans, LA, USA, 2, 10951099. 